\title{
What is going on in early years music planning? A study of early years teachers' weekly plans
}

\author{
Susanne Garvis \\ Griffith University
}

\begin{abstract}
ARTS EDUCATION IS AN Important element of the early years curriculum. Children first learn to express themselves through the arts (dance, drama, media, visual arts and music). Furthermore, numerous studies provide evidence that quality learning experiences in the arts contribute in significant ways to social success and impact positively on a child's academic achievement and long-term education. In Australia, early years teachers are expected to teach arts education.

This study explored the weekly planning of 76 early years teachers across kindergartens, preparatory classes and Years 1, 2 and 3 in Queensland, Australia. Settings took a structured 'curriculum-focused' approach to learning in the early years, which made the exploration of planning important. Our study looked for segments of time devoted to music throughout the week. Content analysis was used to interpret the weekly plans, with three themes emerging: (1) The majority of the weekly plans were dedicated to literacy and numeracy; (2) Little time was devoted to the teaching of music apart from the scheduled 30-minute music lesson with a specialist teacher in some schools; and (3) Of the limited number of weekly plans that featured music, activities were teacher-directed. These results provide insight to the current understanding and value of music education in the early years curriculum. Key messages can be drawn about the importance of professional development, music advocacy in the early years, and curriculum and policy planning.
\end{abstract}

\section{Introduction}

Advocates for arts education have continuously argued the importance of the arts in the early childhood classroom (see Eisner, 2002). The arts offer very young children significant ways of knowing about themselves, others and the world (Wright, 2003). Yet little is known about the way the arts are planned for and used in early childhood classrooms. As an essential part of the curriculum, the arts are assumed to be taught on a regular basis to children and that generalist teachers are responsible for this.

This study was conducted in Queensland, Australia. In Queensland, arts are defined as dance, drama, media, visual arts and music. This study will focus on music. In 2010, early childhood teachers throughout Queensland were asked to respond to a questionnaire. Seventytwo teachers returned the questionnaire with a copy of their weekly planning. Teachers were based in 'structured' early years contexts that had a 'curriculumfocus' on learning. They were currently registered with the Queensland College of Teachers and worked in
Kindergarten, Preparatory, or Years 1, 2 or 3. Registered teachers generally hold a Bachelor of Education degree or a Graduate Diploma of Education.

Content analysis was conducted on the weekly planning sheets to reveal current levels of planning for music. Findings from the sample suggest limited time was devoted to music in the early childhood teachers' weekly planning, and the scheduled activities were teacher-directed. The plans focused largely on literacy and numeracy over the school week.

\section{Literature review}

\section{Early childhood education}

Within early childhood education, art has been recognised for its contribution to the developing child (Bresler, 1992; McWhinnie, 1992; Spodek, 1993). Developmentalism supports the romantic notion that every child is an artist (James, Jenks \& Prout, 1998), with Gardner (2004) asserting that the early childhood years are 'a time when every child sparkles with 
artistry' (p. 86). Wright (2003) also suggests the arts are an important means of self-expression.

It is important to note the influence of training experiences and how they translate into early childhood curriculum. Research has shown that teachers specifically trained in early childhood education provide higher quality care than those without such specialised training (Honig, 1995; Honig \& Hirallal, 1998). Research also suggests, however, that early childhood teachers have low levels of teacher self-efficacy for teaching the arts to young children (Garvis, Twigg \& Pendergast, 2011). These low levels of confidence mean early childhood teachers may provide limited arts learning experiences in their classroom.

\section{Queensland, Australia}

In Queensland, registered teachers work in Kindergarten (children aged 3.5-4.5 years ), Preparatory (children must turn 5 years old by June of the year being enrolled), Year 1 (children aged 6), Year 2 (children aged 7) and Year 3 (children aged 8). The early years consists of children from birth to eight years. The Early Years Learning Framework (DEEWR, 2009) is currently being implemented in prior-to-formal school settings but not in school settings. Teachers in Queensland Kindergarten can use an accredited learning program as the curriculum, such as the Queensland Kindergarten Learning Guideline (OSA, 2009), although they will also need to use the Early Years Learning Framework. Teachers in Preparatory-Year 3 can use learning programs designated by the school.

Both the Early Years Learning Framework (DEEWR, 2009) and the Queensland Kindergarten Learning Guideline (OSA, 2009) advocate a child-centred approach. A child-centred curriculum offers children the opportunity to make choices about what, how and with whom they want to play. This approach enables children to initiate and direct their own play with the support of interested and responsive adults.

Arts education in Queensland is defined as dance, drama, media, visual arts and music. It is expected that the arts are taught by generalist teachers, even in early childhood education (see Queensland Kindergarten Learning Guideline (OSA, 2009), Essential Learning Statements for the Arts (OSA, 2007) and Queensland Early Years Curriculum Guidelines (QSA, 2006). Previous research suggests that arts education is less than satisfactory in many schools (Garvis, 2010; Jeanneret, 1994; Mills, 1989; Russell-Bowie, 1993). Little is known about the content and practice within early years programs and the weekly planning that occurs as part of the curriculum.

In this post-modern world the curriculum can be conceived, conceptualised and experienced in different ways. Goodlad (1979) makes a distinction between the ideal, the formal, the operational, the perceived and the experienced curriculum. The ideal curriculum is the beliefs about what we know and the way we ought to teach. The formal curriculum is that ideal transformed into texts and instructional materials. The operational curriculum unfolds in our daily interactions with children in classrooms. The perceived curriculum refers to the teacher's sense of what is being taught and learned. The experienced curriculum represents the students' point of view. Sometimes a mismatch occurred between what the teacher chose to teach in the curriculum and what children experienced. For example, in the case studies of Stake, Bresler and Mabry (1991), there was a difference between schools' advocacy for arts education and the reality in schools and classrooms.

\section{Music}

Music is seen as a natural part of children's lives. Young children enjoy singing, moving, dancing, creating their own compositions and engaging with musical instruments. Music is connected to play, with musical activities laying the foundation for learning (Bridges, 1994; Campbell \& Scott-Kassner, 2006).

The musical nurturing a child receives during the early years can have a marked impact on later success in music and level of involvement (Feirerabend, 1990) and on adult attitudes towards music (Temmerman, 1995).

Research suggests that early childhood teachers play an important role in providing children with musical experiences. Music can become part of the children's day, whether this be singing songs and rhymes as part of care routines, or responding to, encouraging, talking about, and joining in children's spontaneous musical play (Young, 2003). The teachers' role includes (1) encouraging musical creativity; (2) providing opportunities for engaging with musical instruments; and (3) advising parents on suitable extra-curricula music programs. Parents also hold high expectations about early years teachers and music. According to de Vries (2007), parents believed that preschool and other educational settings provided a complete musical experience for children.

Barrett (2006) has explored the area of music creativity in early childhood, exploring ways that children compose and record their compositions with invented notation. She suggests it is important that 'children's musical agency as song makers and the unique processes and practice of children's communities of musical practice are valued, celebrated and fostered in early childhood settings' (Barrett, 2006, p. 218).

In recent years there has been a considerable amount of research related to children's learning to play a musical instrument. Wright (1991) suggested that early childhood centres should have a wide variety 
of instruments, including piano, guitar, banjo, violin, trumpet, and multicultural percussion instruments, to help children explore sound in a variety of ways including manipulating objects; imitating sounds; discriminating between sounds; classifying sounds; sequencing sounds; improvising with instruments; and organising sounds to communicate ideas and feelings (Wright, 1991).

The role of the early childhood teacher also extends to advising parents about suitable activities for music. Olson and Hyson (2005, p. 67) state 'we should do a better job communicating our role as reliable credible sources of information and support'.

\section{Focus of the study}

In this study, early years teachers are defined as registered teachers working in the early years of schooling (Kindergarten, Preparatory, Years 1, 2 or 3). This study is focused on music education planning by early years teachers in Queensland. It will explore the type and amount of music planned in different early years settings. Even though the Early Years Learning Framework advocates a 'child-focused' approach, this study will show that some settings have a 'curriculum-focused' approach in the early years. The study will also provide an overview of the most dominant subjects in teachers' weekly planning.

Teachers are registered with the Queensland College of Teachers and usually hold a Bachelor of Education or a Graduate Diploma of Education. Registered teachers in this study may or may not have had specialist training in the early years.

Planning is important in Queensland schools, especially with the introduction of school audits in 2010 as part of a new state initiative (see Queensland Roadmap for Curriculum, Teaching, Assessment and Reporting in Years 1-9, Education Queensland, 2009). Teachers must demonstrate their planning in these school audits and show that all curriculum areas have been covered. While teacher plans point to a very teacher-directed approach and may not align with some contemporary practice in early childhood, they are important for investigation, especially for teachers working in the early years of Queensland primary schools (Preparatory, Years 1, 2 or 3). They suggest more of a formalised approach to teaching and learning. Some Kindergartens in Queensland have adapted a similar approach, with structured daily planning. This study explores planning for music in these formalised environments (curriculum-centred approach).

\section{Method}

Data was collected through a brief questionnaire (electronic) which included questions about demographics and asked the participants to submit their weekly plan. The questionnaire was designed to be completed in less than 15 minutes, and outside of school hours. It was distributed, via convenience and snowball sampling, to early childhood teachers in Kindergarten, Prep and Years 1, 2 and 3. Online professional networks were also used to promote this study.

Early childhood teachers were encouraged to return the questionnaire by email or post. Questionnaires returned by email were immediately downloaded and de-identified. Emails were deleted to ensure confidentiality.

The weekly planning was analysed using content analysis_-'a research technique for making replicable and valid inferences from texts (or meaningful matter) to the contexts of their use' (Krippendorff, 2004, p. 18). This process allowed newly identified themes to be compared with previously identified themes to ensure a greater understanding of the phenomenon under study.

\section{Participants}

Seventy-two teachers throughout Queensland participated in this study. Currently there are more than 1300 qualified Kindergarten teachers and 98,429 registered teachers working in the state's early childhood, primary and secondary schools (Queensland College of Teachers, 2009). Participants were located in rural, urban and metropolitan regions. Seventy participants were female $(97 \%)$ and two were male (3\%). Twenty-one per cent ranged in age from 20 to 29 years ( $n=15), 26$ per cent from 30 to 39 years ( $n=19$ ), 31 per cent from 40 to 49 years $(n=22)$, and 22 per cent were aged 50 years or over $(n=16)$. The average age of a registered teacher in Queensland is 43.6 years (Queensland College of Teachers, 2009).

The majority of participants (57\%) held a Bachelor degree $(n=41)$. Fifteen per cent of participants held a diploma $(n=11), 6$ per cent held a Graduate Diploma ( $n=4)$ and 10 per cent held a Masters degree. One participant held an EdD (Professional Doctorate) and 11 per cent chose not to disclose their qualification. Figures align with national figures of early childhood staff qualifications, with data from the 2010 Survey of Education and Work (ABS, 2010) finding 69.7 per cent of early childhood staff have a Bachelor degree or higher qualification. The majority of participants worked in Kindergarten $(n=33)$, followed by Prep $(n=15)$, Year $1(n=10)$, Year $2(n=8)$ and Year $3(n=6)$. All teachers were in 'curriculum-focused' early years classrooms.

Ninety per cent of the participants worked fulltime in the early years ( $n=65$ ). Three per cent were employed part time $(n=2)$ and 7 per cent on a contractual basis ( $n=5)$. 


\section{Results and discussion}

\section{Limited weekly planning for music}

The weekly plans of the 72 teachers were first reviewed to identify any block time periods allocated to music. As previously stated, it is important for primary school teachers in Queensland to demonstrate their planning to school auditors to ensure all curriculum areas have been covered. Planned music sessions (either with a specialist teacher or in class) were evident in 14 per cent $(n=10)$ of the weekly plans (refer to Figure 1); two participants planned extra music sessions on top of a 30-minute music lesson with a specialist teacher; five relied on the music specialist for all music education, and four participants planned their own music sessions in the absence of a music specialist. The music activities planned consisted of teaching students new song repertoires based on the themed unit the students were learning. For example, if the students were studying insects, the planned music time would be designated to learning songs (teacher-chosen) about insects.

Figure 1. Frequency of music in weekly planning

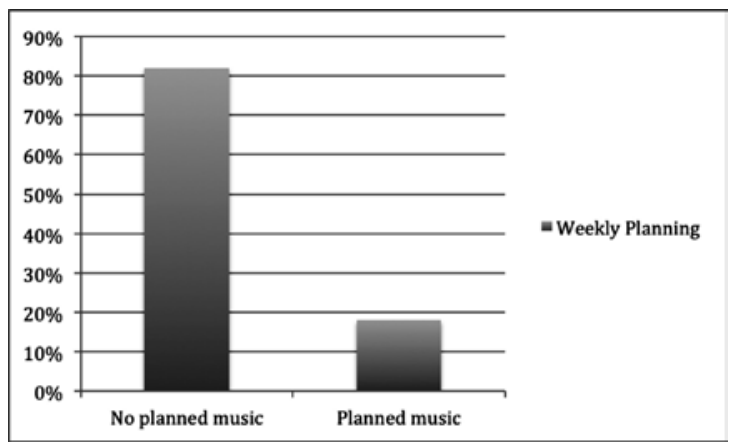

The average amount of time scheduled for music was 30 minutes over the week. Literacy and numeracy appeared to be scheduled for most of the teaching week. In the majority of weekly plans (82\%) literacy was taught until morning tea break, followed by numeracy until lunch. This model was replicated for the entire school week. Literacy activities included spelling, handwriting, phonics and reading. Limited description was given of numeracy activities. The afternoon sessions were planned for other curriculum areas and sport.

In the remaining 18 per cent of weekly plans, a play-based curriculum was evident, with sessions devoted to free play for the child. The teacher would write 'free play' for each of the sessions, without further details of the activities.

While the music specialist sessions were planned in the weekly timetable, this could be more of a structural approach for 'release time'(known as a non-teaching time for planning) within the primary school. In Queensland, release time for generalist classroom teachers is often scheduled when classes spend 30-minute sessions with specialist music and physical education teachers. It is unclear from the weekly plans if early childhood teachers attended music specialist sessions. While music and the arts are an important component of the curriculum in the early years (ideal curriculum), a mismatch may occur in the day-to-day running in the classroom loperational curriculum) where the majority of time is devoted to teaching literacy and numeracy.

The greater time spent on literacy and numeracy in early years classrooms could be a response to the increased pressure for students to perform in national standardised testing for literacy and numeracy in Year 3.

In Australia, arts content knowledge is not tested formally. Without formal accountability, the arts are perceived in a complex way within schools. As Bresler (2002, p. 170) suggests, the arts are 'a by-product of foundation ideas of curriculum that build from the basics or essential knowledge outwards to a the peripheral or less essential knowledge'. The arts may be evident at festivals, special events and on school walls, but are not central to the curriculum even though all subjects are under the title of 'compulsory'. The placement of the arts on the sideline becomes evident in the 72 weekly plans reviewed in the formalised curriculum.

\section{Music activities}

The activities planned for music were teacher-directed, based on increasing the song repertoire. The teacher would choose the song and teach it to the children. Little is known about the song choice or how the songs were taught in the classroom.

According to the weekly plans, limited time was devoted to composition, cultural music and access to musical instruments in the early years classrooms. While the majority of early childhood curricula documents advocate a child-centred approach (especially in the Early Years Learning Framework) this philosophy was not evident in the teacher-directed music activities. Children had no opportunity to experience music beyond the songs taught by the teacher. In essence, the approach of the formalised curriculum in music was in contradiction to contemporary early childhood philosophy.

A gap also emerges between 'school-art' (Bresler, 2002) and musical activities outside of school. Outside of school, children and families may be actively engaged in musical interactions such as singing, playing instruments, listening to recorded music, all nurturing a child's musical development.

It is possible that greater music and arts activities may have occurred within the school in other weeks. This study documented only one week of planning in the life of 72 early childhood teachers. In Queensland there are generally 40 weeks of school in a year. In the lead-up to 
special festivals and school events, more time may have been devoted to music in the weekly planning in the classroom.

\section{Conclusion and recommendations}

Planning is an important area for teachers of the early years in Queensland. If we consider the arts, including music, important for young children we must begin to question our current practice and planning in the early years within schools that advocate a 'curriculum-centred' approach. Is a 'curriculum-centred' approach that appears to limit music suitable? How important is a weekly plan when working with young children? As early childhood educators, we must consider 'growing from the roots' upwards with young children. Such beliefs about a 'child-centred' approach are evident in the Early Years Learning Framework (DEEWR, 2009) but are not put into current practice.

With the decline in hours dedicated to music during generalist teacher education, it is not surprising that early childhood teachers in this study devote limited time to music in their weekly plans.

Our research findings raise more questions than solutions about the role of music in schools with young children. Greater research is needed to determine why early childhood teachers in formalised early years settings plan in the way they do, and if their teaching philosophies match the expectations from schools and early childhood services.

\section{References}

Australian Bureau of Statistics (ABS) (2010). Survey of Education and Work. Retrieved 16 October 2011, from http://www.abs.gov.au/ ausstats/abs@.nsf/mf/6227.0.

Australian Government Department of Education, Employment and Workplace Relations (DEEWR) for the Council of Australian Governments (2009). Belonging, Being and Becoming: The Early Years Learning Framework for Australia. Canberra: Commonwealth Government.

Barrett, M. (2006). Inventing songs, inventing worlds: the 'genesis' of creative thought and activity in young children's lives. International Journal of Early Years Education, 14(3), 201-220.

Bresler, L. (1992). Visual art in primary grades: A portrait and analysis. Early Childhood Research Quarterly, 7, 397-414.

Bresler, L. (2002). School art as a hybrid genre. In L. Bresler \& M Thompson (Eds), The arts in children's lives (pp.169-183). Netherlands: Kluwer Academic Publishers.

Bridges, D. (1994). Music, young children and you. New York: Holt, Rinehart and Winston.

Campbell, P. S., \& Scott-Kassner, C. (2006). Music in childhood: From preschool through the elementary grades. Belmont, CA: Thomson Schirmer Press.

De Vries, P. (2007). The use of music CDs and DVDs in the home with the under-fives. Australian Journal of Early Childhood, 32(4), 18-21.

Education Queensland (2009). Queensland Roadmap for Curriculum, Teaching, Assessment and Reporting in Years 1-9. Brisbane: Queensland Government.

Eisner, E. W. (2002). The arts and the creation of mind. New Haven, CT: Yale University Press.
Feirerabend, J. (1990). Music in early childhood. Design for Arts in Education, 91(6), 15-20.

Gardner, H. (2004). Frames of mind: The theory of multiple intelligences (20th anniversary edn). New York: Basic Books.

Garvis, S. (2010). An investigation of beginning teacher self-efficacy for arts education. (Doctoral Dissertation, University of Queensland, 2010).

Garvis, S., Twigg, D., \& Pendergast, D. (2011). Breaking the negative cycle: The formation of self-efficacy beliefs in the arts. A focus on professional experience in pre-service teacher education. Australian Journal of Early Childhood, 36(2), 36-41.

Goodlad, J.,(1979). Curriculum Inquiry: The study of curriculum practice. New York: McGraw-Hill.

Honig, A. (1995). Choosing childcare for young children. In M. Bornstein (Ed), Handbook for parenting (Vol. 4). Mahwah, NJ: Erlbaum.

Honig, A., \&Hirallal, A. (1998). Which counts more for excellence in childcare staff: Years in service, education level, or ECE coursework? Early Childhood Development and Care, 145, 31-46.

James, A., Jenks, C., \& Prout, A. (1998). Theorizing childhood. Cambridge, UK: Polity Press in association with Blackwell Publishers Ltd.

Jeanneret, N. (1994). Teaching music K-6: Confidence and the Preservice Primary Teacher. Proceedings of the 16th Annual Conference of the Australian Music Education Lecturers Association, Melbourne, pp. 78-91.

Krippendorff, K. (2004). Content analysis: An introduction to its methodology, (2nd edn). Beverly Hills, CA: Sage.

McWhinnie, H. J. (1992). Art in early childhood education. In C. Seefeldt (Ed), The early childhood curriculum: A review of current research (pp. 264-285). New York: Teachers College Press.

Mills, J. (1989). The generalist primary teacher of music: A problem of confidence. British Journal of Music Education, 6(2), 125-138.

Olson, M., \& Hyson, M. (2005). NAEYC explores parental perspectives on early childhood. Young Children, May, 66-68.

Queensland College of Teachers (2009). Queensland College of Teachers Annual Report 2009. Retrieved 16 October 2011, from http:// www.qct.edu.au/publications/Corporate/QCT_Annual_Report_2009. pdf.

Queensland Studies Authority (QSA) (2006). Queensland Early Years Curriculum Guidelines. Brisbane: QSA.

Queensland Studies Authority (QSA) (2007). Arts essential learnings years 1-9. Brisbane: QSA.

Queensland Studies Authority (QSA) (2009). Kindergarten Learning Guideline. Brisbane: QSA.

Russell-Bowie, D. (1993). Where is music education in our primary schools? Research Studies in Music Education, 1, 40-51.

Spodek, B. (1993). Selecting activities in the arts for early childhood education. Art Education in Early Childhood, 94(6), 11-17.

Stake, R., Bresler, L., \& Mabry, L. (1991). Custom and cherishing: The arts in elementary schools. Urbana Champaign, ILL: Council for Research in Music Education.

Temmerman, N. (1995). Children's Perceived Best and Worst Classroom Music Experiences. Proceedings of the 10th National Conference of the Australian Society for Music Education (ASME), Hobart, Australia, pp. 262-266.

Wright, S. (1991). The art in early childhood. Brookvale, NSW: Prentice Hall.

Wright, S. (Ed) (2003). Children, meaning-making and the arts. Australia: Prentice Hall.

Young, S. (2003). Time-space structuring in spontaneous play on educational percussion instruments among three- and four-year-olds. British Journal of Music Education, 20(1), 45-59. 